\title{
PENDIDIKAN KESEHATAN TENTANG OLAHRAGA YANG BENAR DI MASA PANDEMI COVID-19
}

\section{HEALTH EDUCATION ABOUT PROPER EXERCISE DURING THE COVID-19 PANDEMIC}

\author{
Anastasia Putu Martha Anggarani ${ }^{1}$, Raditya Kurniawan Djoar², Riza Amaliya ${ }^{3}$,Tobias Septian Gamma \\ Virgino ${ }^{4}$ \\ ${ }^{1}$ Prodi Fisioterapi STIKES Katolik St.Vincentius a Paulo, Surabaya, Indonesia \\ ${ }^{2}$ Prodi Keperawatan STIKES Katolik St.Vincentius a Paulo, Surabaya, Indonesia \\ ${ }^{3}$ Prodi Ilmu Keperawatan STIKES Katolik St. Vincentius a Pulo, Surabaya, Indonesia \\ ${ }^{4}$ Prodi Fisioterapi STIKES Katolik St.Vincentius a Paulo, Surabaya, Indonesia \\ anastasiamartha88@gmail.com
}

\begin{abstract}
ABSTRAK
Pada akhir tahun 2019 terjadi wabah virus corona baru yang diberi nama 2019-novel corona virus (SARSCoV-2) di kota wuhan, provinsi Hubei, China. Virus ini mulai masuk ke Indonesia pada sekitar bulan Februari 2020. Sehingga semua kegiatan termasuk olah raga harus dilakukan didalam rumah ataupun kalau di luar rumah harus dilakukan dengan cermat. Banyak orang menganggap yang penting olah raga dengan jarak terpisah minimal satu meter dan memakai masker sudah cukup aman. Kegiatan pengabdian masyarakat ini bertujuan untuk memberikan edukasi kepada masyarakat mengenai cara melakukan olahraga yang baik dan benar di masa pandemic covid-19. Kegiatan pengabdian masyarakat dilakukan pada bulan Juni 2021 dengan mengadakan penyuluhan secara langsung dengan media poster, lembar balik dan leaflet dengan anggota terbatas dan penerapan protokol kesehatan dan daring. Seluruh proses kegiatan ini dilakukan selama 2 bulan. Setelah dilakukan proses pendidikan kesehatan didapatkan perubahan prosentase tingkat pengetahuan warga tentang olahraga yang benar dimasa pandemic covid 19 adalah 6 orang (22\%) mempunyai tingkat pengetahuan baik, 11 orang (40\%) mempunyai tingkat pengetahuan sedang dan 10 orang (38\%) mempunyai tingkat pengetahuan kurang. Sedangkan setelah mengikuti pendidikan kesehatan didapatkan bahwa: 2 orang (7\%) mempunyai tingkat pengetahuan sedang dan 25 orang (93\%) mempunyai tingkat pengetahuan baik. Berdasarkan kegiatan tersebut menunjukkan bahwa pendidikan kesehatan dapat meningkatkan pengetahuan responden mengenai olah raga yang benar dimasa pandemic covid 19, disisi lain responden diharap tetap memakai masker, menjaga jarak dan tidak berkerumun saat berolahraga di luar ruangan, dan mencuci tangan setelah selesai olahraga. Olahraga yang baik di lakukan selama masa pandemic covid-19 adalah olahraga dengan intensitas sedang.
\end{abstract}

Kata Kunci : Olahraga, Pandemic, Pendidikan Kesehatan

\begin{abstract}
At the end of 2019, there was an outbreak of a new corona virus named 2019-novel coronavirus (SARS-CoV2) in the city of wuhan, Hubei province, China. This virus began to enter Indonesia around February 2020. So all activities including sports must be carried out indoors or outside the home must be done carefully. Many people think that it is important to exercise at a distance of at least one meter apart and wearing a mask is safe enough. This community service activity aims to provide education to the public about how to do sports properly and correctly during the COVID-19 pandemic. Community service activities are carried out by holding direct and online counseling with limited members and implementing health protocols. The whole process of this activity was carried out for 2 months. After the health education process was carried out, it was found that the percentage change in the level of citizen knowledge about sports during the COVID-19 pandemic was 6 people (22\%) having a good level of knowledge, 11 people (40\%) having a moderate level of knowledge and 10 people (38\%) having a high level of knowledge. less knowledge. Meanwhile, after attending health education, it was found that: 2 people (7\%) had a moderate level of knowledge and 25 people (93\%) had a good level of knowledge. Based on these activities, shows that health education can increase respondents' knowledge about proper exercise during the covid 19 pandemic, respondents are expected to continue to wear masks, keep their distance, and not a crowd when exercising outdoors, and wash their hands after finishing sports. The best exercise to do during the COVID-19 pandemic is moderate-intensity exercise
\end{abstract}

Keywords: Sport, Pandemics, Health Education 


\section{PENDAHULUAN}

Pandemi COVID-19 pada tahun 2020 membawa banyak perubahan dalam kehidupan masyarakat (Woods et al., 2020). Semua harus dilakukan di rumah. Belajar, bekerja, beribadah, bahkan olahraga dianjurkan di rumah. Sebenarnya olahraga bisa dilakukan di luar rumah maupun di dalam rumah. Namun, di masa pandemi corona, olahraga harus dilakukan dengan cermat dan dipertimbangkan dengan seksama.

Banyak orang menganggap yang penting olahraga dengan jarak terpisah minimal satu meter dan memakai masker sudah cukup aman. Padahal tidak semua olahraga di luar ruangan itu aman (Halabchi, Ahmadinejad, \& SelkGhaffari, 2020). Berdasarkan survey pendahuluan yang dilakukan, hal tersebut juga dialami warga RW VI Kelurahan Darmo Surabaya. Mereka mengabaikan protokol kesehatan saat melakukan olahraga, khususnya senam. Senam tetap dilakukan dengan jarak tidak aman dan beberapa peserta tidak menggunakan masker meskipun dilakukan di ruangan terbuka. Beberapa warga juga sering melakukan olahraga bersepeda secara berkelompok dengan penggunaan masker yang tidak sesuai kaidahnya.

Olahraga sebenarnya memiliki banyak efek positif. Manfaat positif olahraga adalah meningkatkan perkembangan pribadi dan psikososial, tidur lebih nyenyak, bahkan dapat mengurangi ketergantungan terhadap alkohol (Lopez V.F.J., Rodriguez G.P.L., Garcia, C.E., Perez, 2016). Efek olahraga juga bisa negatif jika dilakukan berlebihan, misalnya kelelahan (burnout) dan cedera (Malm, C., Jakobsson, J., 2019). Di masa pandemi ini, haruslah dipilih olahraga yang baik. Jika tidak memilih olahraga yang tepat, bukan tidak mungkin dengan berolahraga malah berisiko terjadi peningkatan penularan COVID-19 (Fisiologi FK-KMK, 2020).

Permasalahan Warga RW VI Kelurahan Darmo Surabayatidak memiliki pengetahuan yang baik mengenai kesehatan terutama mengenai COVID-19 dan olahraga yang tepat di masa pandemi COVID-19. Mereka merasa tidak memiliki penyakit apapun dan masih percaya bahwa penyakit dan kematian adalah sudah kehendak Tuhan. Hal tersebut menyebabkan warga tidak melakukan protokol kesehatan saat melakukan olahraga sehingga risiko penularan COVID-19 lebih banyak.

Solusi untuk permasalahan untuk mengatasi permasalahan tersebut, sebagai bentuk pelaksanaan Tri Dharma Perguruan Tinggi, maka kami melakukan pendidikan kesehatan mengenai olahraga yang benar di masa pandemic COVID-19 kepada warga RW VI Kelurahan Darmo Surabaya. Pendidikan kesehatan dilakukan langsung di salah satu rumah warga dengan melakukan protokol kesehatan. Jumlah peserta yang hadir hanya sebagian sedangkan sisanya mengikuti penyuluhan melalui daring. Kegiatan ini dilaksanakan pada bulan Juni 2021.

Hal yang harus dilakukan bila melakukan olahraga di fasilitas umum olahraga adalah melakukan desinfeksi semua peralatan sebelum dan setelah olahraga, cuci tangan dengan sabun minimal 20 detik dan dikeringkan dengan handuk bersih atau tisu sekali pakai. Hand sanitizer 60\% dianggap kurang efektif. Selain itu wajib menghindari menyentuh wajah dan leher dengan tangan sebelum mencuci tangan secara bersih (Zhu, 2020).

Rekomendasi olahraga untuk orang yang sehat yaitu dianjurkan untuk olahraga di lingkungan pribadi dengan ventilasi yang bagus dan menggunakan alat pribadi. Untuk penderita infeksi saluran pernapasan atas dengan gejala hanya terbatas di atas leher, maka diperbolehkan olahraga ringan sekitar 10 menit dengan tes jogging dahulu, jika kondisi memburuk, maka segera dihentikan dan tidak boleh olahraga sampai sembuh sempurna (Yuliana, 2020). Pasien dengan gejala mengalami sakit otot, demam, dan ada gejala saluran cerna, maupun sesak napas atau gangguan organ lain, maka tidak diperbolehkan sama sekali untuk berolahraga sampai sembuh sempurna. Pada masa pandemi ini, semua orang tidak diperbolehkan melakukan olahraga dengan intensitas tinggi, bahkan harus membatalkan semua olahraga kompetisi (perlombaan). Hal ini dilakukan karena orang yang tidak menunjukkan gejala infeksi corona pun dapat menularkan penyakit pada orang lain (carrier) (Halabchi et al., 2020).

Rekomendasi lainnya adalah semua anak dan remaja mulai umur 6-17 tahun disarankan 
olahraga 60 menit sehari dengan intensitas sedang (American College of Sports Medicine, 2020). Jika olahraga intensitas tinggi, maka frekuensi dapat diperpendek menjadi 3 kali seminggu. Jenis olahraga ini dapat pula diikuti dengan aktivitas penguatan otot 3 kali seminggu. Berlari dan melompat diperbolehkan untuk meningkatkan densitas tulang (Malm, C., Jakobsson, J., 2019). Bagi kelompok usia 1864 tahun, WHO menyarankan untuk berolahraga minimal 150 menit seminggu dengan intensitas sedang. Jika dilakukan dengan intensitas tinggi disarankan 75 menit seminggu yang terbagi dalam 3 kali pertemuan. Latihan penguatan otot disarankan 2 kali seminggu. Untuk usia di atas 64 tahun lebih disarankan untuk latihan kekuatan otot dan keseimbangan (Malm, C., Jakobsson, J., 2019).

Olahraga yang paling aman dilakukan dimasa pandemic covid-19 adalah olahraga yang dilakukan di rumah yaitu berjalan di dalam rumah, latihan kekuatan, peregangan, dan latihan keseimbangan. Sepeda statis, latihan kombinasi, naik turun tangga, senam, yoga, angkat beban, sit up, push up ataupun jalan santai di luar rumah masih diperbolehkan sambil menjaga jarak aman. Namun, olahraga di tempat umum dan lingkungan padat akan membawa risiko penularan yang lebih besar (Chen. P., Mao, L., Nassis, G.P., Harmer, P., Ainsworth, B.E., Li, 2020). Olahraga sebaiknya dilakukan minimal 30 menit dengan intensitas sedang setiap hari. Alternatif lain adalah dilakukan 20 menit dengan intensitas berat (Luan, X., Tian, X., Zhang, H., Huang, R., Li, N., Chen, P., 2019; Zhu, 2020).

Beberapa faktor yang penting dimonitor selama olahraga adalah beban latihan/olahraga, pemulihan, dan sakit/cedera (Herlina \& Suherman, 2020). Beban latihan meliputi lamanya latihan, frekuensi, dan intensitas. Yang diperhatikan saat pemulihan adalah denyut jantung saat istirahat, kelelahan, nafsu makan, dan kualitas tidur. Frekuensi, tipe, penyebab, tempat/posisi tubuh terjadinya sakit/cedera, serta berapa lama waktu terjadinya sakit/cedera adalah hal penting yang tidak boleh dilewatkan (Malm, C., Jakobsson, J., 2019). Dengan memonitor berbagai hal tersebut secara mandiri, diharapkan olahraga bisa berlangsung aman dan meningkatkan imunitas pada masa pandemi corona ini.

\section{METODE}

Ketua RW VI Kelurahan Darmo Surabaya mengirim surat permohonan dilaksanakan penyuluhan. Ketua program pengabdian masyarakat membuat proposal rencana kegiatan pemberian pendidikan kesehatan. Setelah proposal disetujui oleh ketua LPPM dan Ketua STIKES St. Vincentius A Paulo Surabaya, maka akan dikeluarkan surat tugas. Setelah mendapatkan surat tugas, maka dilakukan kegiatan survey lokasi dan diskusi terbatas dengan pengurus. Setelah itu, tim menyusun kegaiatan yang akan dilakukan yaitu pemberian pendidikan kesehatan yang diawali dengan pemberian kuesioner. Pendidikan kesehatan secara langsung dengan jumlah peserta terbatas dan dilakkan dalam waktu 30 menit. Selain itu penyuluhan ini juga dilakukan secara daring dalam waktu yang sama sehingga bisa lebih banyak warga yang dapat mengikuti penyuluhan. Setelah melakukan tanya jawab, warga diberikan kuesioner mengenai olahraga yang benar di masa pandemi. Hasil kuesioner pre dan post pendidikan kesehatan selanjutnya diolah sehingga didapatkan hasil tingkat pengetahuan sebelum dan sesudah diberikan pendidikan kesehatan. Setelah pelaksanaan pendidikan kesehatan akan dilakukan pemantauan oleh tim terhadap pelaksanaan olahraga yang biasa dilakukan oleh warga. Tim mengevaluasi kembali mengenai tingkat pengetahuan warga dalam implementasi olahraga yang benar di masa pandemic. Seluruh kegiatan berlangsung selama 2 bulan.

\section{HASIL DAN PEMBAHASAN HASIL}

Terdapat 27 warga yang mengikuti penyuluhan baik secara daring maupun luring. Hasil tingkat pengetahuan warga tentang olahraga yang benar dimasa pandemic COVID 19 adalah 6 orang (22\%) mempunyai tingkat pengetahuan baik, 11 orang (40\%) mempunyai tingkat pengetahuan sedang dan 10 orang (38\%) mempunyai tingkat pengetahuan kurang. Sedangkan setelah mengikuti pendidikan kesehatan didapatkan bahwa : 2 orang (7\%) mempunyai tingkat pengetahuan sedang dan 25 
orang (93\%) mempunyai tingkat pengetahuan baik
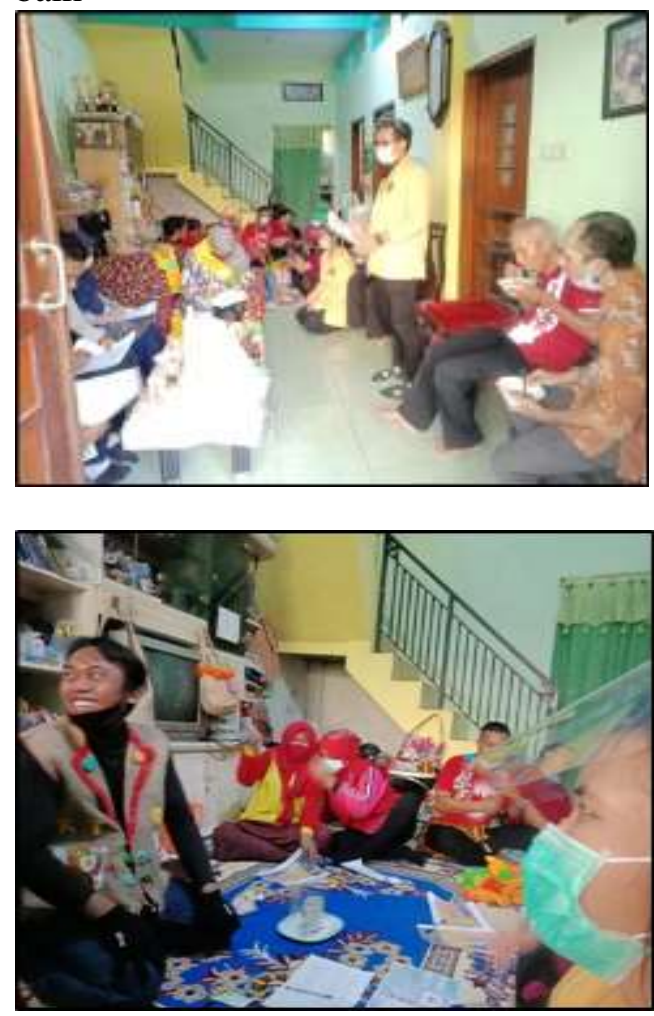

Gambar 1 Proses Pendidikan Kesehatan

\section{PEMBAHASAN}

olah raga merupakan kebutuhan yang penting bagi manusia, karena dengan berolah raga tubuh dapat tetap terjaga kebugarannya terlebih lagi dimasa pandemi sekarang ini. Apabila kita rajin berolahraga tubuh akan menjadi bugar dan memiliki sistem imun yang kuat yang dapat menangkal kuman, bakteri dan virus (Kamil, I. L., Sukman, H., Rahma, F., Sartika, D., 2020). Namun hal ini berbeda dengan hasil yang didapatkan saat kegiatan pengabdian masyarakat di RW VI kelurahan Darmo Surabaya. Dalam kegiatan tersebut menunjukkan bahwa sebanyak 11 orang (40\%) warga memiliki tingkat pengetahuan sedang tentang olah raga, mereka merasa tidak memiliki penyakit apapun dan percaya bahwa penyakit dari kematian adalah kehendak dari tuhan. Hal ini dapat menyebabkan warga mudah terpapar covid 19. Untuk meningkatkan pengetahuan, warga diberikan pendidikan kesehatan disalah satu rumah warga dengan tetap melakukan protokol kesehatan melalui daring. Berdasarkan hasil pendidikan kesehatan yang telah diberikan, didapatkan tingkat pengetahuan warga meningkat. Sebanyak 25 orang (93\%) mempunyai tingkat pengetahuan baik. Hal ini menunjukkan bahwa edukasi kesehatan sangat diperlukan untuk meningkatkan pengetahauan. Pendapat ini sejalan dengan (Irawan, E., Arif, S., Hakim, A. R., Fadly, U. F., Hadi, S., \& Pertiwi, 2020) bahwa edukasi kesehatan pada masyarakat menyadarkan manusia bahwa sesungguhnya pendidikan kesehatan itu sangat penting dalam meningkatkan kesehatan dan perilaku masyarakat dan individu kapanpun dan dimanapun. Kegiatan ini berjalan dengan baik, sebanyak 27 warga mengikuti penyuluhan secara langsung maupun daring. Responden dapat menerima informasi yang diberikan penyuluh dengan baik. Penyuluh secara singkat memberikan pertanyaan untuk mengevaluasi efektivitas penyuluhan. $100 \%$ peserta baik peserta yang mengikuti kegiatan secara langsung maupun yang daring dapat menjawab pertanyaan dari penyuluh. Lalu didapatkan hasil tingkat pengetahuan warga tentang olah raga dimasa pandemic covid 19 sebanyak 6 orang $(22 \%)$ mempunyai tingkat pengetahuan baik, 11 orang (40\%) mempunyai tingkat pengetahuan sedang dan 10 orang (38\%) lainnya mempunyai tingkat pengetahuan kurang. Setelah warga mengikuti pendidikan kesehatan, hasil yang didapatkan pun vberbeda yaitu sebanyak 2 orang (7\%) mempunyai tingkat pengetahuan sedang dan 25 (93\%) mempunyai pengetahuan baik.

\section{KESIMPULAN}

Pendidikan kesehatan dapat meningkatkan pengetahuan warga mengenai olahraga yang benar dimasa pandemi covid 19 dengan data: hasil tingkat pengetahuan warga tentang olah raga yang benar dimasa pandemi covid 19 sebelum mengikuti pendidikan kesehatan adalah $22 \%$ mempunyai tingkat pengetahuan baik, $40 \%$ mempunyai tingkat pengetahuan sedang dan $38 \%$ mempunyai tingkat pengetahua kurang. Sedangkan setelah mengikuti pendidikan kesehatan didapatkan bahwa $7 \%$ mempunyai tingkat pengetahuan sedang dan $93 \%$ mempunyai tingkat pengetahuan baik. 
Saran bagi warga yang mengikuti pendidikan kesehatan dan masyarakat Indonesia secara umum adalah diharapkan tetap memakai masker, menjaga jarak dan tidak berkerumun saat berolahraga di luar ruangan, dan mencuci tangan setelah selesai olahraga. Olahraga yang baik di lakukan selama masa pandemic covid-19 adalah olahraga dengan intensitas sedang. Untuk mengurangi risiko tertularnya virus covid-19, olahraga yang paling aman adalah olahraga yang dilakukan sendiri di rumah misalnya, senam, olahraga dengan beban ringan, dll.

\section{DAFTAR PUSTAKA}

American College of Sports Medicine. (2020, October 20). Staying Active During the Coronavirus Pandemic. American College of Sports Medicine.

Chen. P., Mao, L., Nassis, G.P., Harmer, P., Ainsworth, B.E., Li, F. (2020). Wuhan coronavirus (2019-nCoV): The need to maintain regular physical activity while taking precautions. Journal Sport Health Science, 9(2), 103-104.

Fisiologi FK-KMK, U. (2020). Mengapa harus tetap beraktivitas fisik di tengah pandemi Covid-19? Universitas Gajah Mada, 125.

Halabchi, F., Ahmadinejad, Z., \& SelkGhaffari, M. (2020). COVID-19 epidemic: Exercise or not to exercise; That is the Question! Asian Journal of Sports Medicine, 11(1), 17-19. https://doi.org/10.5812/asjsm.102630

Herlina, H., \& Suherman, M. (2020). Potensi Pembelajaran Pendidikan Jasmani Olahraga Dan Kesehatan (Pjok) Di Tengah Pandemi Corona Virus Disease (Covid)-19 Di Sekolah Dasar. Tadulako Journal Sport Sciences And Physical Education, 8(1), 1-7. Retrieved from http://jurnal.untad.ac.id/jurnal/index.php/ PJKR/article/view/16186
Irawan, E., Arif, S., Hakim, A. R., Fadly, U. F., Hadi, S., \& Pertiwi, F. N. (2020). Pendidikan Tinggi Dimasa Pandemi Transformasi, Adaptasi, dan Metamorfosis Menyongsong New Normal. Sleman: Zahir Publishing.

Kamil, I. L., Sukman, H., Rahma, F., Sartika, D., \& M. (2020). Bersama Melawan Covid-19. Parepare: IAIN Parepare Nusantara Press.

Lopez V.F.J., Rodriguez G.P.L., Garcia, C.E., Perez, S. J. . (2016). Relationship between sport and physical activity and alcohol consumption among adolescents students in Murcia. Archivos Argentinos de Pediatria, (114), 101-106.

Luan, X., Tian, X., Zhang, H., Huang, R., Li, N., Chen, P., et al. (2019). Exercise as a prescription for patients with various diseases. Journal Sport Health Science, (8), 422-441.

Malm, C., Jakobsson, J., I. A. (2019). Physical Activity and Sports-Real Health Benefits: A Review with Insight into the Public Health of Sweden. Sport, 7(127), $1-28$.

Woods, J. A., Hutchinson, N. T., Powers, S. K., Roberts, W. O., Gomez-Cabrera, M. C., Radak, Z., ... Ji, L. L. (2020). The COVID-19 pandemic and physical activity. Sports Medicine and Health Science, 2(2), 55-64. https://doi.org/10.1016/j.smhs.2020.05.00 6

Yuliana. (2020). Olahraga yang Aman di Masa Pandemi COVID-19 untuk Meningkatkan Imunitas Tubuh. Jurnal Bali Membangun Bali, 1(2), 103-110. https://doi.org/10.51172/jbmb.v1i2.112

Zhu, W. (2020). Should, and how can, exercise be done during a coronavirus outbreak? An interview with Dr. Jeffrey A. Woods. Journal Sport Health Science, (9), 105107. 